\title{
PROBLEMATIKA ADAPTACE CIZÍCH SLOV V ČEŠTINĚ
}

\author{
Hanne-Lore Bobáková
}

Klíčová slova v češtině:

Interference, adaptace, cizí slovo, fonologie, morfologie, sémantika, ortografie, stylistika

\section{Klíčová slova v angličtině:}

Interference, adaptation, foreign words, phonology, morphology, semantics, orthography, stylistics

\begin{abstract}
Abstrakt v češtině
Článek se zabývá problematickými otázkami adaptace cizích slov anglického původu. Navazuje na př́íspěvky $\mathrm{k}$ této problematice $\mathrm{v}$ minulosti a přináší jejich doplnění o pohled $\mathrm{z}$ hlediska česko-anglické interference a o aktuální otázky jejich adaptace. V článku je poukázáno na složitost adaptačních procesů přejímání cizích slov. Tř́fázovost daného procesu je demonstrována na příkladech získaných excerpcí z aktuálních slovníků.
\end{abstract}

\section{Abstrakt v angličtině}

The article deals with some questions of foreign words of English origin adaptation. It follows the works published in the past, and focus on the completion with respect to the phenomenon of the Czech and English interference. The contribution points at the complexity of the adaptation process, which is illustrated by some examples, obtained from current dictionaries excerption.

\section{Úvod}

O problematice interference mezi jazyky u cizích slov se pojednávalo např. v článcích Margy Firle a Aleny Hovorkové (1979) „Die faux amis unter Fremdwörtern im Deutschen und im Tschechischen“ a později v článku Karla Franka (1980) „Česko-německá interference u cizích slov.“ Na zmiňované př́spěvky bychom navázali a doplnili je o problematiku cizích slov anglického původu.

Jak bylo v prvně jmenovaném článku správně konstatováno, jsou z hlediska porozumění nejzávažnější otázkou nežádoucí interference v oblasti sémantické. (Frank 1980, s. 118). Cizí slovo získává vlivem nežádoucí interference pojmenování z mateřského jazyka. Autoři článku upozornili na prrípady, kdy existuje $\mathrm{v}$ češtině řada cizích slov, avšak němčina používá jen slovo domácí. K. Frank (1980, s. 118) upozornil na to, že popsaný jev může platit i obráceně. ${ }^{1}$

\section{Aspekty přejímání cizích slov}

Cizí slova přejatá z cizího jazyka do češtiny procházejí složitým procesem. Z minulosti víme, že tímto procesem prošly všechny jazyky v důsledku hospodářských, politických a kulturních změn či kontaktů daného národa. Mnohdy se může stát, že původ cizího slova zdomácní natolik, že nevzbuzuje sebemenší pochybnost o jiném než českém původu. Stačí si

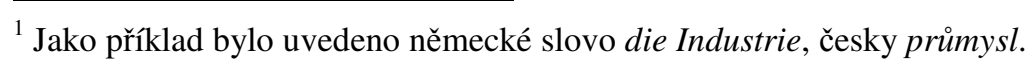


připomenout slovo džem, u kterého došlo $\mathrm{k}$ plné ortografické a fonologické adaptaci a tím k zastření cizího původu tohoto slova. ${ }^{2}$

Zmiňovaná skutečnost vede k úvahám o cizosti slov. Pojem cizost slova je ovlivněn relativností daného vnímání. Nebudeme se zabývat skupinou slov, u kterých již není jasný původ. Zaměříme se na druhou skupinu cizích slov, u nichž cizost stále cítíme. Vycházíme z K. Hausenblase (1974, s. 266) a jeho dělení cizích slov.

Shodně s Frankem zastáváme názor, že u cizích slov se nelze omezit pouze na negativní dopad jejich transferu na sémantiku slova. Vedle sémantického transferu je zapotřebí zdůraznit fonetické, prosodické, morfologické a syntaktické vlastnosti.

Cizí slova bývala $\mathrm{v}$ lingvistice analyzována $\mathrm{z}$ hlediska diachronního, čili $\mathrm{v}$ popředí stála etymologie slova. Vedle diachronního pohledu je z hlediska současnosti důležité hledisko synchronní, nebot' synchronní pohled totiž umožňuje zkoumání stupně začleněnosti cizího slova v jazykovém systému, konkrétně znaků, jimiž se cizí slova odlišují od domácí slovní zásoby.

Novější pohled na internacionalizaci a nacionalizaci při přejímání cizích slov se objevuje v monografii Slowotwórstwo/ Nominacjaa. Nacionalizací se rozumí manifestace specifických rysů národního jazyka v podmínkách těsného jazykového kontaktu (Martincová 2003, s. 18). Hovoří se v tomto kontextu o vyrovnávacích procesech projevujících se ve vytváření domácích protějšků k neologickým přejímkám. Ponecháváme stranou typy nacionalizačních tendencí od ortoepické, ortografické a morfologické roviny až po rovinu sémantickou.

Mezi internacionalizací a vyrovnávacími tendencemi se spatřují jisté souvislosti:

1. Přejímání lexikálních prostředků (internacionalizace) a proces dotváření domácích protějšků (vyrovnávací tendence) naznačuje, že v mnoha případech neexistují domácí protějšky k přejímkám nebo tyto nemají stejnou komunikační platnost. Liší se expresivitou a nižším stupněm uzualizace, mohou však vystupovat jako konkurenční prostředky.

2. Je zaznamenán nárůst internacionálních afixoidů a radixoidů (Martincová 2003, s. 22).

Není možné nevzpomenout skutečnost, že tendence k internacionalizaci představuje proces zvyšování podílu a funkční zátěže slovotvorných a lexikálních prvků cizojazyčného původu v slovní zásobě současných spisovných jazyků (Gazda 2003, s. 64). Z tohoto pohledu přináší internacionalizační tendence rozvoj slovní zásoby.

Fonetická rovina českého jazyka je odlišná od fonetické roviny anglického jazyka. Slova cizí jak po stránce morfologické, ortografické či fonetické tvoří vyhraněnou část slovní zásoby a jako taková podléhají specifickým podmínkám adaptace (viz níže):

- all-road/all road (kategorie automobilů s luxusním vybavením);

- best of (best of známého zpěváka);

- blue chip (dobře obchodovatelné akcie);

- callback/call-back (call back služby);

- casual (casual móda);

- dial-up (dial up poplatek);

- $\operatorname{dot}$-com (dot com firma) ${ }^{3}$

\footnotetext{
${ }^{2} \mathrm{~V}$ tomto př́padě je třeba mít na zrételi vliv politických okolností, vedoucích $\mathrm{k}$ úplné adaptaci slova. Pro socialistický systém bylo zcela nežádoucí připomínat vliv západního jazyka na jazyk český.
} 
- fast food (fast food jídla);

- gender (gender studia) ${ }^{4}$

- go-go/go-go girl ${ }^{5}$ (eroticky vyhlížející dívka).

Vybraná skupina cizích slov v tomto případě ukazuje, že cizí slovo přichází s novým pojmem. V reálném světě vznikne nová skutečnost a nové pojmenování skutečnosti. Uživatel jazyka přejímá danou skutečnost i pojmenování samé. V první fázi nedochází nebo nemusí docházet k adaptaci fonetické, grafické či morfologické. Dokladem toho jsou nesklonná neadaptovaná adjektiva či substantiva (casual móda, dial up poplatek, fast food jídla). Časem se některá cizí slova adaptují. Slovo bestovka je př́íkladem adaptace cizího slova takovým způsobem, aby co nejvíce vyhovovala jazykovým zvyklostem. Konotace slova je hovorová. Původní cizí slovo nenese zatížení vedlejšími významy nebo stylistickými a expresivními příznaky. Při procesu zdomácnění cizího slova bezpříznakovost časem mizí.

V německém jazyce není adaptace tak zřetelná jako v českém jazyce. Němčina také neadaptuje některá adjektiva (easy), u jiných slov se anglický výraz začleňuje do německého morfologického systému (slovo cool). ${ }^{6}$

Cizí slovo fast food se mění v hovorovou variantu fastfudy. Se změnou stylu dochází i ke změně v morfologické adaptaci. Z původně nesklonného substantiva se stává substantivum mužského rodu. Podobně je tomu u slova best of (best of známého zpěváka). Bestovka je již plně adaptované substantivum ženského rodu.

Zmiňme krátce obecné zásady spisovné výslovnosti cizích slov. Specifičnost výslovnosti spočívá v tom, že hlásková podoba anglického jazyka není shodná s hláskovou podobou českého jazyka. Výsledkem této skutečnosti je fonetická adaptace v rámci českého hláskového systému. ${ }^{8}$

Z hlediska fonetického se adaptace cizích slov rrídí určitými zásadami. Fonémy anglického jazyka, které čeština nemá, se nahrazují foneticky nejbližšími domácími hláskami. Aspirované souhlásky [p] [t] [k] se nahrazují českými ekvivalenty těchto hlásek.

Dále platí, že při neexistenci hlásky v češtině je výslovnost vedena směrem k nejblíže odpovídající hlásce v češtině. Jedná se o znělé polozávěrové hlásky, coby znělé protějšky c a č. Již ve článku zmiňované slovo džem je toho dokladem.

Za anglické neznělé [e] se v češtině vyslovuje bud' plné [e] nebo samohláska, která se $\mathrm{v}$ anglickém slově píše [e].

Jak jsme shodně s M. Dokulilem (1986, s. 103) mohli pozorovat, procházejí cizí slova v adaptačním procesu př́ejímání a zdomácňování třemi stupni:

\footnotetext{
${ }^{3}$ Označuje firmu působící na internetu.

${ }^{4}$ Znamená psychologicky a interkulturně podmíněné rozdíly mezi mužským a ženským pokolením.

${ }^{5}$ Znamená eroticky vyhlížející děvče.

${ }^{6}$ Coole Frau, cooles Mädchen.

${ }^{7}$ Jedná se o př́íklad zdomácnělého cizího slova, tedy slova zcela přizpůsobeného formou, hláskovou stavbou a mluvnicky.

${ }^{8}$ Pro srovnání jen uved'me, že $\mathrm{v}$ němčině se přistupuje $\mathrm{k}$ procesu přejímání obdobně. Navíc jsou při přejímání použity ještě hlásky, jež se vyskytují pouze $\mathrm{v}$ cizích slovech $\mathrm{s}$ jejich nezměněnou původní zvukovou podobou. Týká se to nosovek i některých souhlásek (flirt x $r$ Flirt, šance x e Chance, manekýn x s Mannequin, bronz x e Bronze).
} 
1. Slova zcela přizpůsobená domácímu jazykovému systému ve výslovnosti i pravopise (e-mail);

2. Slova částečně adaptovaná české výslovnosti a pravopisu (mailovat);

3. Slova neadaptovaná (mejl).

První příklad znázorňuje počáteční fázi přizpůsobení. V této fázi je slovo pocit’ováno jako cizí.

Druhý př́klad demonstruje morfologickou adaptaci. Přizpůsobení se českému jazykovému systému probíhá odvozováním pomocí verbálního sufixu -ovat.

Ve třetím prrípadě se anglická varianta slova přizpůsobila foneticky i ortograficky českému jazykovému systému. Úplná adaptace je konotována příznakem běžné hovorové komunikace. Př́iklad demonstruje konečnou fázi procesu přejímání cizího slova.

Podle míry adaptace je možné kompozita třídit do těchto skupin:

1. Neadaptovaná kompozita, to znamená taková, která se ortograficky a morfologicky neadaptovala;

2. Kompozita morfologicky adaptovaná ale ortograficky neadaptovaná;

3. Ortograficky a morfologicky adaptovaná kompozita;

4. Hybridní kompozita (Svobodová 1999, s. 126).

Jistě není bez zajímavosti, že způsob adaptace sloves cizího původu v poslední době narůstá. Jako př́klad uved'me slovesa odvozená od anglického spojení hand in cap. V češtině se setkáváme s přejímáním sloves i podstatného jména. Zaznamenali jsme varianty handicapovat i hendikepovat, handicap $i$ hendikep. Domníváme se, že zvolené př́klady jasně naznačují, že čeština bude mít i v budoucnu potřebu úplné adaptace, tedy i adaptace v rovině ortografické. ${ }^{9}$

Hranice mezi adaptovanými, částečně adaptovanými a neadaptovanými cizími slovy není plynulá. Charakteristiku procesu si nejlépe uvědomíme na morfologické adaptaci. K demonstraci použijeme např. adjektivum cool. Je zajímavé, že v češtině se prosazuje toto adjektivum jako nesklonné. $Z$ hlediska sémantického může být použito ve více kontextech, jednak ve významu báječný, senzační ( cool značka oděvu), jednak ve významu nejnovější, aktuální (cool novinky).

Z hlediska morfologického se jedná o slovo nesklonné, čili neadaptované. Př́íklady ukazují, že u slova cool má jazykový systém češtiny problém se začleněním. Čeština jako jinak flexivní jazyk nezačleňuje slovo cool pomocí slovotvorných prostředků do systému české flexe.

Příčiny jevu hledejme v konotacích. Slovo cool má své domácí ekvivalenty, kterými jsou zmiňovaná adjektiva báječný, senzační, nejnovější, aktuální. Vedle sebe tak stojí domácí ekvivalenty a cizí slovo. Cizím denotátem je demonstrován expresivní náboj výpovědi. Jinými slovy neutrální, bezpříznaková výpověd' použitím neadaptovaného adjektiva posouvá výpověd' do stylisticky příznakové roviny. ${ }^{10}$ Slova jsou synonymní, používají se stejně, avšak ze stylistického hlediska mohou svým př́iznakem text obohatit.

\footnotetext{
${ }^{9}$ Otázkou ale zůstává, zda slovesa handicapovat a hendikepovat mají v našem jazyce své opodstatnění. Hendikepovat.

${ }^{10}$ Zajímavé je zjiššení, že v němčině u slova cool dochází k morfologické adaptaci (cooles Mädchen).
} 
Zmiňme ještě krátce stylistickou konkurenci mezi adaptovanými a neadaptovanými cizími slovy. K tomu nám poslouží např. genderová lingvistika a gender studia. Je pozoruhodné, že přes formální rozdílnost je u nich zachována sémantická kongruence. Využití lexikálních dublet tak pokládáme za projev obohacení slovní zásoby v lexikální rovině, na straně druhé hodnotíme stylistickou diferenciaci jako projev aktualizace a intelektualizace jazyka.

Z hlediska interference je důležitá otázka mluvnického rodu. Interferenční jevy způsobují transfer mluvnického rodu do němčiny. Český mluvčí má určitý rod zafixován a převádí jej automaticky do jiného jazyka. Viz příklady uvedené K. Frankem (1980, s. 119). Vychází z němčiny a uvádí př́iklady cizích slov jako Dokument, Transparent, Diktat, Exponat, Bar, Grapefruit.

\begin{tabular}{|l|l|}
\hline němčina & čeština \\
\hline Brainstorming $N$ & brainstorming $M$ \\
\hline Briefing $N$ & brífing $M$, tiskovka $F$ \\
\hline Cash Flow $M$ & cash flow $M$ \\
\hline Controlling $N$ & controlling $M$ \\
\hline Factoring $N$ & factoring $M$ \\
\hline Franchising $N$ & frančíza, koncese $F$ \\
\hline Image $N$ & image $M, F, N$ \\
\hline Factoring $N$ & faktoring $M$ \\
\hline Know-how $N$ & know-how $N$ \\
\hline Leasing $N$ & leasing $M$ \\
\hline Public Relations $P L$ & public relations, agentura, práce s veřejností \\
\hline
\end{tabular}

V němčině se anglické výrazy končící sufixem -ing nepřekládají do němčiny. Ortograficky zůstávají beze změn, výslovnost odpovídá anglické výslovnosti. V českém jazyce často existují stylistické varianty briefing/tisková konference/tiskovka, nebo př́klady úplné adaptace franchising/frančiza/koncese. $\mathrm{V}$ případě lexému merchandising se v češtině používá český překlad tvorba, formování nabídky. Úplná adaptace cizího slova dokládá skutečnost, že cizí slovo se již plně začlenilo do jazykového systému, navíc vytvořilo konkurenční synonymní dvojici. Na demonstrovaných prríkladech jsme nezaznamenali prŕípady posunu významu, ke kterému obvykle dochází při přejímání cizích slov.

Zastavme se ještě krátce u prriřazování substantiva k prŕíslušnému rodu. U cizích slov pozorujeme negativní působení interferenci v přiřazování k mluvnickému rodu. Anglicizmy v němčině jako Bodybuilding, Bodyforming, Bodyshaping a Bodystyling. Tato substantiva jsou v němčině rodu středního. V češtině zaznamenáváme rod mužský (Bodybuilding sportovní kulturistika: věnovat se bodybuildingu).

Při zkoumání anglicizmů v českém jazyce jsme zjistili, že přiřazování substantiva k rodu není zcela jednoznačné, stává se, že substantiva lze přiřadit $\mathrm{k}$ více rodům:Best of $(\mathrm{N}, \mathrm{M})$, just in time $(\mathrm{M}, \mathrm{N})$, kango jumps $(\mathrm{F}, \mathrm{Pl})$, laser show $(\mathrm{F}, \mathrm{N})$, last minute $(\mathrm{M}, \mathrm{N})$, last moment $(\mathrm{M}, \mathrm{N})$, live show $(\mathrm{F}, \mathrm{N})$, offshore $(\mathrm{M}, \mathrm{N})$, oldies $(\mathrm{M}, \mathrm{F} \mathrm{Pl})$, sales promotion $(\mathrm{F}, \mathrm{N})$, self promotion $(\mathrm{F}$, $\mathrm{N})$, teen movie $(\mathrm{F}, \mathrm{N})$, welfare $(\mathrm{M}, \mathrm{N})$.

V této souvislosti se v češtině zachovávají jisté principy, připomeňme si je ve stručnosti:

1. Lexikální podobnost

die City - die Stadt

das Girl-das Mädchen 
ten šlágr - ten hit

2. Přirozený rod

der Gentleman

der Playboy

gentleman, playboy $(M)$, au pair (au-pair), barbie, showgirl $(F)$.

Také cizí slova au pair (au-pair), barbie, showgirl se do českého systému časem začleňují, k základu substantiva přibírají české sufixy a plně se vjazyce adaptují: au-pair - aupairka,barbie - barbína.

3. Morfologický aspekt - zakončení substantiva

Rodově determinující zakončení jsou v češtině spíše vzácností. Mnohá substantiva integrovaná do českého jazyka mají zakončení, které je nezvyklé pro domácí lexikální systém. Integrace takových př́ípadů je složitější. Zpravidla je těmto substantivům přiřazen střední rod.: fantasy, know-how, love story.

4. Analogické znaky v rámci skupiny

der Alkohol - der Drink

ten Alkohol - ten drink

hot line/hot-line - ta horká linka

der Tanz-der Rap

ten tanec-ten rap

Problematické přiřazování $\mathrm{k}$ rodu v češtině si ukážeme na dalších příkladech. Jedná se např. o př́ípady, kdy zjištění daného rodu je možné jen z určitého kontextu. Např. slovo image může znamenat podoba $(\mathrm{F})$, vzhled $(\mathrm{M})$, vizáž $(\mathrm{F})$, renomé $(\mathrm{N})$.

image $(M, F, N)$,

know how/know-how $(M, N)$.

Vedle interferenčních jevů krátce zmíníme rozkolísanost ortografickou, která platí pro oba jazyky. Porovnejme napřr. pravopisné dublety v němčině:

- Bodybuilding;

- Bodyshaping/Body-Shaping;

- Bodystyling/Body-Styling;

- Bodydrill/Body-Drill;

- Bodystocking/Body-Stocking.

Také v češtině se objevuje rozkolísanost v pravopise. Složená slova se píší různým způsobem:

- Dohromady;

- Zvlášt';

- Se spojníkem.

Rozkolísanost v pravopise se týká také adjektivních kompozit:

- Callback, call-back (zpětné volání);

- Call centrum, callcentrum (střediska poskytující na zavolání informace);

- Citybus, city-bus (městský autobus).

\section{Závěr}

K přejímání slov cizího původu dochází pravidelně. Docházelo k němu již v nejstarších obdobích vývoje jazyka, dochází k němu v současném období ještě výrazněji. Důvody vidíme v narůstající potřebě pojmenovávat nové skutečnosti a sdělení lépe stylisticky diferencovat. 
Analýza problematiky adaptace cizích slov anglického původu jasně ukázala, jak složitý je proces začleňování cizích prvků do domácího jazykového systému. Cizí slova se adaptují různým způsobem. V průběhu procesu někdy vytvářejí konkurenční varianty a přispívají tím k stylistické zabarvenosti komunikátu. Považujeme tento jev za nástroj stylistické pestrosti v jazyce.

Formální rozdílnost mezi adaptovaným a neadaptovaným cizím slovem nebrání sémantické kongruenci. Lexikální dublety se tak stávají projevem obohacení slovní zásoby v lexikální rovině a dokládají stylistickou diferenciaci a intelektualizaci jazyka.

Dále je třeba poznamenat, že přejímaná cizí slova bývají často synonymy k českým výrazům. Původní české slovo může být pod vlivem různých asociací a konotací, cizí slovo může zesilovat význam slova expresivně.

Současné evropské jazyky jsou vystaveny působení celosvětové globalizace projevující se v oblasti politiky, hospodářství, kultury i jazyka. Z lingvistického hlediska se globalizační tendence projevují internacionalizací a nacionalizací lexika. Xenofilní a xenofóbní snahy jsou společné evropským jazykům ve větší či menší míře a odrážejí skutečný stav globalizující se společnosti, jejímž př́ínakem je univerzalizace a hybridizace kultury a způsobu života, v neposlední řadě univerzalizace kulturních a morálních hodnot.

V prŕíspěvku jsme se zabývali adaptací cizích výrazů pouze z hlediska osamocených lexémů, ty však do systému každého jazyka zasahují především prostřednictvím konkrétního kontextu.

\section{Literatura:}

[1] BOZDĚCHOVÁ, I. Vliv angličtiny na češtinu. In: Český jazyk na přelomu tisíciletí. Praha: Academia, 1997, s. 271 - 279. ISBN 80-200-0617-6.

[2] BUZASSYOVÁ, K. K dimenziám internacionalizácie slovnej zásoby. In: Internacionalizmy v nové slovní zásobě. Slovník příspěvků z konference. Praha 16. - 18. června 2003. Praha: UJČ, 2003. s. 5 - 15. ISBN 80-86496-11-2.

[3] DANEŠ, F. Jazyk vědy. In: Český jazyk na přelomu tisíciletí. Praha: Academia, 1997, s. 68 - 83. ISBN 80-200-0617-6.

[4] DOKULIL, M. Mluvnice češtiny 1. Fonetika Fonologie Morfologie a morfemika. Tvoření slov. 1. vyd. Praha: Academia, 1986.

[5] FIRLE, M., HOVORKOVÁ, A Die faux amis unter Fremdwörtern im Deutschen und im Tschechischen. In: Cizí jazyky ve škole, XXIII, 1979/80, s. 262 - 267.

[6] FRANK, K. Česko-německá interference u cizích slov. In: Cizí jazyka ve škole, XXIII, 1979/80, s. $118-122$.

[7] GAZDA, J Internacionalizační tendence v rozvoji slovní zásoby současných západoslovanských jazyků. In: Neologizmy v dnešní češtině. Praha: Ústav pro jazyk český Akademie věd České republiky, 2005, s. 64 - 73. ISBN 80-86496-21-X.

[8] HAUSENBLAS, K. Čeština za školou. 1. vyd. Praha: Orbis, 1974. ISBN 505-22-825.

[9] MARTINCOVÁ, O., RANGELOVÁ, A., SVĚTLÁ, J. Neologizmy v dnešní češtině. 1. vyd. Praha: Ústav pro jazyk český Akademie věd České republiky, 2005, 248s, ISBN 80-86496-21-X.

[10] SVOBODOVÁ, D. Anglické výrazy v českém publicistickém stylu. In: Naše řeč 79, s. 99 -102. ISSN 0027-8203.

[11] SVOBODOVÁ, D. Anglická hybridní kompozita v současné češtině a jejich adaptace. In: Naše řě 82, 122 - 126. ISSN 0027-8203. 
[12] SVOBODOVÁ, D. Anglicismy přejímané do češtiny v původní plurálové formě. In: Naše řeč 83, s. 55. ISSN 0027-8203.

[13] ZEMAN, J. Problémy se skloňováním: Stanley cup 1993 aneb McSorley, Robitaille a ti druzí. In: Naše řeč 80, 81 - 87. ISSN 0027-8203.

\section{JEL klasifikace: Y800}

PhDr. Hanne-Lore Bobáková, Ph.D.

Katedra cizích jazyků a komunikace

Obchodně podnikatelská fakulta v Karviné

Slezská univerzita v Opavě

Univerzitní náměstí 1934/3

73340 Karviná

bobakova@opf.slu.cz 